Мирослава Сливка кандидат філологічних наук, дочент, дочент кафедри англійської філології ДВНЗ «Ужггородський національний університет», orcid.org/0000-0002-8673-7147, м.Ужгорд, Украӥна, +38 (050)2167442, myroslava.slyvka@uzhnu.edu.ua Наталія Сливка ст.викладач кафедри іноземних мов факультету іноземної філології ДВНЗ «УжНУ» ORCID 0000-0001-7894-8553 Ужггород, Україна, nataliia.slyvka@uzhnи.еdu.иа

\title{
Reproduction of stylistic features and functions of original metaphors in translation
}

Анотація. Дана стаття присвячена вивченню перекладу метафор, беручи до уваги різні класифікащії та погляди провідних науковців перекладознавиів на способи їх перекладу на різні мови. Метою роботи $\epsilon$ порівняння та вивчення метафори в перекладі, беручи до уваги природність звучання, психологічне та культурне навантаження. Об'єктом вивчення є твори Стівена Кінга «Безсоння» та «Сяйво» та їх переклади, виконані I. Андрусяком i K. Борисенко. В роботі окреслено стилістичні функиіі метафор та способи їх перекладу. В результаті проведеного аналізу встановлено, щзо більшість типів $i$ функиій метафор була збережена перекладачами. Метафоричність творів Стівена Кінга вражає, саме тому переклад його оригінальних метафор представляє неабиякі труднощі для перекладача, як культурні так і лінгвістичні. Усі оригінальні метафори були перекладені відповідно до теоретичних засад висвітлених в роботі.

Ключові слова: переклад, метафора, перекладознавство, еквівалентність, оригінальні метафори.

Abstract. The article deals with the analysis of metaphor translation, taking into account different ways of their classifications and views of leading translation studies scholars on their rendering into different languages. This paper also examines stylistic value of metaphors in the literary text and concludes that stylistic equivalence is one of the most important issues in translation. The metaphor should correspond to the original grammatically, lexically, contextually and culturally. The study is based on the idea of possible applications of modern cognitive linguistics to the study of metaphors in the original text and its translation. The combination of cognitive and traditional methods of analysis of translational transformations opens up new prospects for the development of the 
theory and practice of translation. It can characterize more fully the general laws of the particular translation of the text and identify the individual characteristics of the works of individual translators. The metaphor can be translated either literally or via paraphrasing or using the substitution techniques. Moreover, the translator should have special skills and competences which will allow them to render the text in accordance with common rules, norms and principles. It is a key problem for metaphor translation as soon as the interpreter is obliged to connect unusual impression and emotional features of the source text to the perception of the reader of the target text. The most numerous category in Stephen King's works is original metaphors. The evidence proves that, all metaphors were rendered without destruction of meaning, even if functions did not correspond in ST and TT, the meaning was conveyed fully and properly.

Keywords: metaphor, equivalence, rendering, translator, metaphor translation

Introduction. Metaphor is an extremely powerful stylistic device. It bears an enormous emotional charge and simultaneously uncovers main features of the literary text. Metaphor can be an outstanding device which shows author's thoughts and way of thinking. Within centuries people have been interested in them. Understanding of metaphors still is a challenge for linguists, psychologists and translation studies scholars. Different types of metaphors can overlap and be confused that is why it is important to differentiate at least the most vivid sides of each of them. Stylistically metaphors influence the text in such a way that it becomes challenging both for the reader and the translator.

The field of metaphor translation and analysis is not explored to the very end. Previously, there were attempts to classify metaphors. The main contribution was made by the outstanding Soviet scholar Skliarevskaya G. in her book "Metaphor in the system of language". She outlined all possible functions of metaphors depending on various conditions. Also V. Teliya, V. Gak in their work "Metaphors in the text" tried to classify metaphors and describe the way they are produced and understood. As to the foreign scholars, G. Lakoff and M. Johnsen in their book "Metaphors we live by" showed different ways of metaphor perception and creation. Moreover, they touched the problem of conceptual metaphors. Of the utmost importance are psychological studies by Dr. Gibbs who explicitly shows how the human brain work when producing and percepting metaphorical expressions. The field of metaphor translation is quiet new and unexplored. Only some scholars worked in it. Among them R. Zorivchak, a prominent Lviv scholar, who in her works gave some pieces of advice how to translate different types of metaphors. P. Newmark suggests different ways of metaphor translation according to their type. However, Cognitive Linguistics provides scholars with fruitful data concerning metaphor formation and metaphor understanding. Among scholars who have been working in this particular field of linguistics and psychology are: Yan, Kovecses, Noen, Wolf, Kaur and Mandelbit. 
This paper is an attempt to analyze translation of metaphors, taking into account different ways of their classifications and views of leading translation studies scholars on their rendering into different languages. The topicality of the paper is determined by vague data concerning analysis of metaphors in Stephen King's works in Ukrainian literature as well as Translation Studies in Ukraine. The linguistic scope of metaphor translation has to be extended permanently as soon as metaphor have a unique possibility to enrich the language with new figurative, thought provoking and bright metaphorical expressions, under condition they were translated properly and naturally.

The objects of our paper are metaphors in Stephen King's novels "The Shining" and "Insomnia" and their translations made by Ivan Andrusyak and $\mathrm{K}$. Borysenko. Two novels and two translations were chosen for the research with the aim to understand and analyze different metaphors in the source text and two different translators' techniques applied in the translations. The subject of the paper is stylistic features of reproduction of metaphors along with their functions in the literary text.

The material of the research is grounded on theoretical works of the leading linguists, psychologists and translation studies scholars, also dictionaries, electronic online dictionaries, encyclopedias and online recourses.

The overall aim is to specify ways of metaphor reproduction and to summarize all stylistic features of metaphor translation, to state whether their reproduction is successful and corresponds to principles of their translation highlighted in the research.

The objectives of the research are:

1) to analyze the nature of the metaphor as a stylistic device;

2) to discuss some ways of metaphor translation developed by linguists and translation studies scholars;

3) to describe and contrast metaphors in ST and TT in order to see main challenges of metaphor translation and ability of the translator to render them adequately, preserving style and the very metaphor.

The methodology of our research includes contrastive analysis of the original and the translation, taking into account relevant reproduction, context and natural sounding of metaphors. The methodology of the present research is based on the theory of metaphor translation, actively elaborated and developed by home and foreign linguists, general principles of metaphor theory are of significant importance for the present investigation, as well as the ideas and methods of transformational translation theory.

To address the specific objectives of the study we have used a range of methods, characteristic of contemporary linguistics and translation theory: comparative analysis, taking into account national peculiarities of the languages and cultures, as well as the classification and quantitative processing of the material, elements of quantitative analysis. The selection of metaphors has been 
performed with the help of the method of continuous sampling. Descriptive method has been used in generalizing, organizing, and interpreting the material.

Results and Discusions. Stephen King's novels are very interesting for linguists and Translation Studies scholars. Being highly educated person in literature and being extremely ambitious he uses all achievements of literature, in particular high or elite one. This helps him to enrich stylistic value and expressive language of his masterpieces. Amazing, but Stephen King who is mainly known for his novels, has broadened his horizons to different types of writings such as movie scripts, nonfiction, autobiographies, children's books, and short stories.

For the research the most vivid samples of metaphors were analyzed from novels "The Shining" and "Insomnia" and their translations made by I. Andrusiak and K. Borysenko. I. Andrusiak is a well-known poet. His poetry is very metaphorical, it is almost built on metaphors. That is why his translation of metaphors is expected to be very poetical and unusual. K. Borysenko is a wellknown Ukrainian translator and scholar. Her research into Ukrainian language and literature contributed enormously to Translation Studies and Comparative Linguistics. Along with I. Andrusiak she's translated lots of novels and poems. Their mutual work is regarded to be fruitful and of the high quality. While researching data it would be of particular interest to trace similar and different approaches to metaphor translation. Moreover, we will discuss whether translators managed to reproduce metaphors basing our conclusions not only on natural sounding, degree of clearness for the Ukrainian reader, but also on the theoretical principles established by well-known scholars.

Metaphor has been widely discussed within the discipline of Translation Studies, predominantly with respect to translatability and transfer methods. It has been argued that metaphors can become a translation problem, since transferring them from one language and culture to another one may be hindered by linguistic and cultural differences. A number of translation procedures for dealing with this problem have been suggested by different scholars, e.g., substitution (metaphor into different metaphor), paraphrase (metaphor into sense), or deletion. Such procedures have been commented on both in normative models of translation (how to translate metaphors) and in descriptive models (how metaphors have been dealt with in actual translations).

However, Mary Fung in her work "Translation of Metaphor" states that "in contrast to the voluminous literature on metaphor in the field of literary criticism and rhetoric, the translation of metaphor has been largely neglected by translation theorists" [9, p. 237].

M. B. Dagut remarks: "What determines the translatability of a source language metaphor is not its 'boldness' or 'originality', but rather the extent to which the cultural experience and semantic associations on which it draws are shared by speakers of the particular target language" [7, p. 21-33]. Snell-Hornby expresses a similar viewpoint: "the extent to which a text is translatable varies with the degree to which it is embedded in its own specific culture, also with the 
distance that separates the cultural background of source text and target audience in terms of time and place [13, p. 41].

Translation of metaphors is connected with the solution of a number of linguistic, literary, cultural, philosophical, and other problems. The importance of the proper approach to the study of methods of metaphor translation is determined by the need of adequate transfer of imaginative information and the reconstruction of stylistic effect of the original in the translation. Experts stress the need to maintain the image of the translation, but this is not always possible.

Ya.I. Retsker delineates the following four ways of translating metaphors:

1) Equivalent correspondences. This method of translation may be used if there exist regular correspondences in the target language for the original metaphor. For example, the majority of English trite metaphors have Ukrainian equivalents, fixed in lexicographical sources.

2) Variative correspondences used in each case when there are several methods of translating a metaphorical expression fixed in the dictionary.

3) Transformation. Transformational method requires a complete replacement of the basis of the original metaphor.

4) Loan translation is the restoration of a full analogue of the original metaphor in translation [6].

The complexity of translating metaphor is largely due to differences between the metaphorical systems existing in the relevant languages. For example, the metaphoric images characteristic of the English language are often missing in Ukrainian, and vice versa. While some metaphors are said to be universal present in almost all cultures [2, p.55], other are believed to be culturally specific having no correspondences in other cultures which significantly perplexes translators in their work.

The "law of metaphor preservation" has long been formulated in the theory of translation, according to which the metaphoric image should be preserved wherever possible in translation. The failure to comply with this law leads to the change in the meaning of the phrase, and its aesthetic and pragmatic effect is reduced. As noted by V. Vovk, the omissions of original metaphors are "serious and very common means of distortion" of the author's intention [3, p. 127]. These metaphors enrich TL so according to P. Newmark they should be translated literally. If the meaning is obscure the translator can replace it with the descriptive metaphor.

Original metaphors are individual author's metaphors, which are not used in everyday speech. They represent a great challenge to the translator. They are difficult to translate because they represent author's perception of the world; they show author's style and his features of writing. Moreover they enrich target language as they bring new and interesting associations, collocations. P. Newmark recommends translating them as close as possible to the original not to lose author's style and manner. 
In terms of this theme we would like to show the difference between simile and metaphor because really interesting associations S. King brings to us. Both similes and metaphors link one thing to another. A simile usually uses "as" or "like". A metaphor is a condensed simile, a shortcut to meaning, which omits "as" or "like." A metaphor creates a relationship directly and leaves more to the imagination. With simile A is like B. With metaphor A is B. This type of metaphor is the most interesting for analysis and there are many of them presented in both texts. Examples of metaphors of this type from the novel "The Shining" are as following: "...the early afternoon sun sparkling in it (the lake) like a golden fish snared in a blue net..." [10, p. 41].Simile sun like a golden fish can be traced here. A metaphor here is sun is a golden fish. Its function is image-creating. Simile is easy to understand and metaphor forces us to ponder a bit over it. Without context it is difficult to understand what is going on. Why should sun be a golden fish? Further, looking on the whole situation we can see that it is snared in a blue net of the lake, which means that it is actually a sunset and sun is going to disappear. The translation is the following: “...ранне пообідне сонце блищало в ньому, як піймана в блакитну сіть золота рибка" [4, p.88]. The translator uses very close equivalents, preserves simile and consequently the metaphor but with one totally Ukrainian feature - diminutive suffix in the word рибка. This is a very common feature in the Ukrainian language, which flourishes with them. There are 54 diminutive suffixes in the Ukrainian language and 17 in English. Stylistically it is impossible to reproduce them without any losses, so different modes of translation are applicable here. The very name золота рибка, traces back to O. S. Pushkin's tale "Сказка о рыбаке и рыбке". As a consequence this рыбка is calqued to the Ukrainian language and is widely used, while we have more common names e.g. рибонька. It is better to use рибонька because -оньк - is native Ukrainian diminutive suffix and it sounds naturally. The function of the metaphor is preserved due to the fact that unusual image is present in the target text.

The next sample from this category is: "...the scream is drifting from your mouth like a lazy balloon" [10, p.42]. Metaphor here is scream is a lazy balloon. The function is image-creating as well. Context of this episode is that Wendy stands on the top of the mountain and while talking words travel a long time to the addressee because of the altitude. In the translation we have: “...мов ледача повітряна кулька 3 твого рота пливе крик..." [4, p.90]. This is direct translation with preservation of all figurativeness and definitely the metaphor. Thus the word order is changed to sound more naturally in the Ukrainian language and more poetically. Inversion is used here to highlight this unbelievable feeling of standing on the top of the mountain. Without a context this metaphor would not be understood, which proves that it is an original metaphor. The function is preserved adequately.

The next original metaphor is: "The bitter lock of his emotions was broken" [10, p.196]. In this example we have metaphor the bitter lock of emotions. Lock 
means ' $a$ thing that keeps a door, drawer fastened and is usually opened with a key or by moving a small metal bar' [12]. In the context this metaphor means that the person (main hero Jack Torrance) was trying for a long time to hide his emotions, not to drink alcohol and not to abuse his wife. In Overlook it was difficult for him so his emotions started coming out, he could not restrain his temper any more. The function of the metaphor is cognitive as soon as emotions are inevitable part of human's experience. The translator's variant is: "Гірку греблю емоцій прорвало" [4, p.384]. The rendering is really powerful and for Ukrainians it bears deep connotative meaning, as the expression прорвати греблю means exactly the same as the original expression. It is understandable for Ukrainian readers, because literal translation замок на емоиіях зламався would sound awkward and unnatural. Metaphor here is preserved but paraphrased in order to make sense for the TL reader. The function is preserved as the code of emotions is practically identical in the English and Ukrainian languages.

"The picture of John Torrance, thirty years old, who had once published in Esquire and who had harbored dreams - not at all unreasonable dreams - to become a leading American writer" [10, p.195]. The verb harbor means to keep bad thoughts, fears, or hopes in your mind for a long time or to contain something, especially something hidden and dangerous. The verb deviates from the noun a harbor - a protected area of water next to the land where ships and boats can be safely kept [12]. Most often this verb is used in such a meaning: secretly shelter criminals [12]. In our example we have to harbor dreams, which in this context mean to cherish the thought of something. The function of the metaphor is cognitive because it deals with human's emotions and experience. I. Andrusyak provides us with the following translation: "Джек Торренс, тридиять років, раз опублікувався в Есквайрі, мріяв (як йому здавалося, не так уже й необгрунтовано) стати провідним американським письменником" [4, p.382]. The translation is understandable but the very metaphor is not preserved. The Ukrainian word мріяти is too general and does not have this deep connotative meaning of secretly hiding something from public eye. We would suggest other possible variants: плекав мрї, приховував плани, таємно мріяв, його мрією, схованою безпечно, як корабель в гавані було... The last variant is descriptive and too long for such a sentence, nevertheless it preserves this connection to the sea, ships, it is SL oriented translation produced with the aim to preserve metaphor and a part of figurative meaning.

All following samples are from the novel "Insomnia". As well as metaphors of this kind from the novel "The Shining" they are of the great interest for linguists and translation studies scholars. The first original metaphor with generalizing function appears in sentence: “The frosty air cut about Elen's shoulders keen as a knife" [11, p.91]. Here frosty air is similar to a knife. This is an original metaphor. The comparison is made on the basis of similarity between cold wind or air and sharpness of the knife. As to take metaphoric shifts into account this is objectobject shift, one thing is described through another. Knife usually creates very 
unpleasant and freezing associations in both English and Ukrainian. As a result both words air and knife gain new meanings what is obvious for generalization. The translator renders this metaphor as: "Крижаний вітер шмагав Елен по плечах, мов батіг” [5, p.81]. In the translation the image is totally changed. Knife is changed for lash. The metaphor is preserved but it evokes totally different associations. The collocation шмагати батогом is much more acceptable for the Ukrainian reader. Despite this discrepancy the translation is partial equivalent as grammatical pattern is preserved along with textual cohesion and coherence. As it was previously mentioned it is possible to substitute images in order to make the message sound more naturally.

The next example of the original metaphor is: "Ed tried to interpret the language of his soul" [11, p.9]. In this case the reader can observe Ed's subjectivity in perception of the world. The metaphor here is interpret the language of the soul. It belongs to the stock class of metaphors. In its direct meaning the word interpret means "to translate spoken words from one language into another" or "to believe that something someone does or something that happens has a particular meaning" [8]. In this particular situation and context this word is used figuratively in collocation interpret language of the soul which means to try to explain reality in terms of his particular comprehension [8]. The word language also in this context obtains a new meaning, which is connected with thoughts, comprehension of the outer world through inner communication. Consequently boundaries of this word become wider as conceptual metaphors presuppose it to be.

O. Borysenko suggests the following translation: "Ed викривлював перспективу справжніх душевних почутmів" [5, p.8]. The translator in this case shows his own understanding of the metaphor. The word викривляти in the Ukrainian language has different meaning than the word interpret. It means "перекручувати, спотворювати, показувати у неправильному вигляді" [1]. According to the translation, Ed means intertwisted reality. Then the word перспектива means either "простір, який можна охопити оком; вид у далину" or "спосіб зображення на площині або на кривій поверхні об'ємних предметів такими, якими ми бачимо їх з певної точки спостереження" [1]. In the given context collocation перспектива почуттів could be interpreted as Ed's particular feelings that are understandable only for him. Metaphoric sense is preserved, conceptuality also, thus the implication and meaning are different. In source language Ed tried to understand himself and in target language he misinterpreted reality, destroyed it. If to take into account equivalence of both utterances they are similar only in one domain - pragmatic, because neither word nor grammatical equivalence is preserved. Textual definitely is because the translation is coherent. In the translation pragmatic effect differs from what is implied in the original and is definitely stronger.

"His (Ed's) spirits were always at high-water mark" [11, p.29]. In this case the metaphor where spirits and the high water mark are compared cannot be met in 
every day communication. In its direct meaning high water mark is "the mark that shows the highest level that the sea or a river reaches" [12]. However, this expression has also a figurative meaning "the time when someone or something is most successful" [58]. Neither of these two is depicted in this sample. Eventually, as the novel had been really popular, dictionaries started using this metaphor meaning the highest point of something because it was widely used. If to talk about metaphoric shift it is object-abstraction (water mark is an object and spirits abstract notion). K. Borysenko translated this metaphor as following: "Вона завжди кипіла життям" [5, p.24]. In the Ukrainian language the notion of the water mark does not bear any implication or figurativeness. That is why the translator decided to paraphrase the utterance thus saving the pragmatic effect. The collocation кипіти життям is not a metaphor. It is rather a phraseologism which derives from a metaphor. Consequently to some degree this transformation can be called substitution in order to make the message natural and easy for comprehension. The translation and the original are partial equivalents because only pragmatic aspect of equivalence is preserved.

Very vivid example from the novel "Insomnia" is as following:

“Love doesn't come out of a faucet you can turn on and off whenever you want to...I had to remember my love could not fix him..." [11, p.103]. Love is also one of the most thought provoking notions in the life of each and every individual. Stephen King also pays close attention to love as though his novels are rather thrilling than romantic. One of the metaphors of this field can be encountered in the part where poor woman Helen was widely beaten by her husband despite the fact they were really into each other. The metaphorical expression "love doesn't come out of a faucet" brings into life clear associations of the water which runs through the faucet and can be easily stopped or moved forward which is definitely not possible because human is not a machine and it cannot be operated like this. The metaphor itself is original with visible image creating function. The translation is as following: "Любов-це не водопровідний кран, який можна закрити за власним бажанням...Моя любов не в змозі зупинити Еда...” [5, p.106]. The translation preserves the image of the original: любов-водопровідний кран, the translation awakes the same associations. The tiny difference is that in the translation the metaphor is more obvious linguistically: in the Ukrainian language it is noun-noun metaphor which is like a template whereas in the English language the meaning is hidden in the simple sentence with noun and verb. The function and the type of metaphor are preserved in the translation. The rendering sounds natural and thought-provoking.

Conclusions. Summarizing all original metaphors, their functions and translations, it is evident that they present a great challenge for the translator. Original metaphor, whatever its function is, shows the inner world and to some extent psychology of the author. While translating them the main option is to preserve them even though this metaphor hasn't existed in the world before. 
Original metaphors enrich the vocabulary of both target and source texts. Both translators coped with the task without major losses.

To understand main features and challenges of metaphor translation each scholar must be aware of general theoretical approaches to translation, each approach has its specific features which ought to be preserved while the translation process. The translator's task is to specify the role of the metaphor in the text, its function, context it is used in and type of the metaphor. The metaphor can be translated either literally or via paraphrasing or using the substitution techniques. Moreover, the translator should have special skills and competences which will allow them to render the text in accordance with common rules, norms and principles.

Translation problems are endless and inexhaustible: it can be expected that further development of science and practice will advance new problems into linguists' center of attraction, whose solution will require new methods and techniques while working with the original and translated texts.

\section{REFERENCES}

1. Бусел В. Т. Великий тлумачний словник сучасної украӥнської мови. Ірпінь: Перун, 2001.

2. Вежбицкая А. Сопоставление культур через посредство лексики и прагматики. - М.: Языки славянской культуры, 2001. 286с.

3. Вовк В.Н. Языковая метафора в художественной речи. Природа вторичной номинации. К.: Наукова думка, 1988. 304c.

4. Кінг С. Сяйво. Пер. $з$ англ. І. Андрусяка. Харків: Фоліо, 2010. 635с.

5. Кінг С. Безсоння. Пер. $з$ англ. К. Борисенко. Харків: Фоліо, 2008. 790с.

6. Рецкер Я.И. Пособие по переводу с английского языка на русский язык. М.: Просвещение, 1982.240с.

7. Dagut M.B. Can "Metaphor" be translated? Vol. 22. Babel (1976): 21-33.

8. Encyclopedia Britannica. Available at: http://www.britannica.com.

9. Fung M. M.Y. Translation of Metaphor. An Encyclopaedia of translation. eds. Chan - Sin-wai \& D.E., 1995: 236 - 249.

10. King S. The Shining. New York: Simon and Schuster, 2001. 331p.

11. King S. Insomnia. New York: Penguin Books, 1994. 450p.

12. Longman dictionary of Contemporary English. Available at: http://www.Idoceonline.com.

13. Snell-Hornby M. Translation Studies - An Integrated Approach. Amsterdam /Philadelphia: John Benjamins, 1988. 286p. 